\title{
A felnőttkori hypolactasia születésikohorsz-vizsgálata
}

\author{
Buzás György Miklós dr.
}

Ferencvárosi Egészségügyi Szolgáltató Közhasznú Nonprofit Kft., Budapest

\begin{abstract}
Bevezetés és célkitüzés: A laktázgén promóterében a $\mathrm{C} / \mathrm{T}_{13910}$-fenotípusok prevalenciájának vizsgálata és a születésikohorsz-jelenség tanulmányozása laktózintolerancia tüneteivel rendelkező betegekben.

Módszer: A 2010 és 2017 között végzett tanulmányba 1266 beteg került. A C/ T $_{13910}$-fenotípusokat polimeráz-láncreakcióval határoztuk meg. A betegekből 5 éves születési kohorszokat alakítottunk ki, és a fenotípusok gyakoriságát azokon belül kiszámítottuk.

Eredmények: A CC, TC és TT fenotípusok gyakorisága 43,1\%, 44,3\% és 12,6\% volt. A CC-fenotípus prevalenciája nőkben nemlineárisan fokozatosan emelkedett, az 1939 előtt született egyénekben észlelt 9,13\%-ról az 1995 után születettekben $37,7 \%$-ra.

Következtetés: A laktázgén promóter CC-fenotípusának prevalenciája nőkben fokozatosan növekedett, jelezve a hormonális hatások jelentőségét a születésikohorsz-jelenségben.
\end{abstract}

Orv Hetil. 2019; 160(14): 549-554.

Kulcsszavak: felnőttkori hypolactasia, genetikai teszt, laktózintolerancia, polimorfizmus, születésikohorsz-jelenség

\section{Birth-cohort analysis in adult-type hypolactasia}

Introduction and aim: To assess the prevalence of lactase gene promoter $\mathrm{C} / \mathrm{T}_{13910}$ phenotypes in patients with lactose intolerance symptoms and to analyze the birth-cohort phenomenon in lactose-intolerant patients.

Method: 1266 patients consulted between 2010 and 2017 were enrolled. Five-year cohort periods of patients born before 1939 and after 1995 were defined and the prevalence of $\mathrm{C} / \mathrm{T}_{13910}$ phenotypes was calculated. $\mathrm{C} / \mathrm{T}_{13910}$ phenotypes were determined by polymerase chain reaction.

Results: The prevalence of the CC phenotype was $43.1 \%$, TC was detected in $44.3 \%$ and TT in $12.6 \%$ of the cases. The prevalence of the CC phenotype showed a non-linear incremental increase in females, from $9.13 \%$ in those born before 1939 to $37.7 \%$ in those born after 1995 .

Conclusion: The prevalence of CC phenotype raised incrementally in females, suggesting a gender/hormonal influence.

Keywords: adult-type hypolactasia, birth-cohort phenomenon, genetic test, lactose intolerance, polymorphism

Buzás GyM. [Birth-cohort analysis in adult-type hypolactasia]. Orv Hetil. 2019; 160(14): 549-554.

(Beérkezett: 2018. október 20.; elfogadva: 2018. november 17.)

\section{Rövidítések}

ANOVA $=($ analysis of variance $)$ varianciaanalízis; $\mathrm{CC}=$ citozin-citozin; DNS = dezoxiribonukleinsav; $\mathrm{KSH}=$ Központi Statisztikai Hivatal; OGYÉI = Országos Gyógyszerészeti és Élelmezés-egészségügyi Intézet; PBS = (phosphate buffered saline) foszfáttal pufferolt sóoldat; $\mathrm{PCR}=$ (polymerase chain reaction) polimeráz-láncreakció; $\mathrm{TC}=$ timidin-citozin; $\mathrm{TT}=$ timidin-timidin
A laktózintolerancia, újabb nevén a felnőttkori hypolactasia a leggyakoribb szénhidrát-felszívódási zavar. A kórképpel kapcsolatos újabb ismeretek olvashatók a nemzetközi és hazai közleményekben [1-5]. Az utóbbi években a genetikai háttérrel rendelkező betegségeknek kiemelkedő jelentőséget tulajdonítanak, és azok spektruma folyamatosan bővült: közéjük tartozhat a felnőttkori hypolactasia is [6]. Dolgozatunk célkitűzése a laktázgén 
promóterében lévő $\mathrm{C} / \mathrm{T}_{13910}$-fenotípusok gyakoriságának kiértékelése nagyszámú esetanyagon, valamint a fenotípusok és születési kohorszok közötti összefüggés vizsgálata.

\section{Betegek és módszer}

A vizsgálatba 2010. január 1. és 2017. december 31. között a Ferencvárosi Egészségügyi Szolgáltató Kft. Gasztroenterológia szakrendelésén háziorvosi beutalóval jelentkező, a tejcukor-érzékenység tüneteivel rendelkező (tej, tejtermék fogyasztása után jelentkező puffadás, hasmenés, hasi görcsök) 1266 beteget válogattunk be. Az első 496 esetet retrospektíven, 2010 és 2015 között, a további 770 esetet prospektíven, 2016 és 2017 között vizsgáltuk; a retrospektív eredményeket előző közleményünkben ismertettük [7].

A kórelőzmény felvétele és fizikális vizsgálat után a betegeket tájékoztattuk a genetikai tesztről. A genetikai tesztet önköltséges alapon végeztük, tehát sem az intézetnek, sem a társadalombiztosításnak nem jelentett terhet. A tanulmányba csak olyan betegek kerültek, akiknél a genetikai mintavétel a szakrendelőben, személyes ellenőrzés mellett történt. A beválogatásba csak magyarországi származású, kaukázusi egyének kerültek: ezen belül más etnikai csoportosítás nem történt. A tanulmányt a Ferencvárosi Egészségügyi Szolgáltató KNp Kft. Tudományos és Etikai Bizottsága engedélyezte, az megfelelt a helsinki nyilatkozat elő́rásainak. A genetikai vizsgálat előtt a betegek írásos tájékoztatásban részesültek, és beleegyezésüket adták.

A genetikai teszt a száj nyálkahártyájából törléssel vett mintából készült, amelyet PBS-transzportmédiumba helyeztünk, $4{ }^{\circ} \mathrm{C}$-fokon tároltunk, és a mintákat 24 órán belül a Synlab Budapest Diagnosztikai Központ GenoID Molekuláris Diagnosztikai Laboratóriumába szállították. A DNS-izolálás 96 lyukú lemezen a cég által kifejlesztett mágneses módszerrel történt. A C/ $\mathrm{T}_{13910}$ polimorfizmust irodalmi leírás adaptációjával [8], valós idejü PCRmódszerrel határozták meg. A PCR-vizsgálatokat Step One Plus (Thermo Fisher, Waltham, MA, Egyesült Államok [USA]) készüléken végezték.

\section{Statisztikai elemzés}

A genetikai eredményekből meghatároztuk három, a laktázgén promóterének $\mathrm{C} / \mathrm{T}_{13910^{-}}$es pozíciójában található fenotípusnak a megoszlását (TC: timidin-citozin; CC: citozin-citozin, TT: timidin-timidin) a teljes betegcsoportban, férfiakban és nőkben. A keresztmetszeti vizsgálatban a betegcsoportot születési évük szerint, 5 éves kohorszokba ${ }^{1}$ soroltuk [9-13], melyekben kiszámí-

\footnotetext{
' A születésikohorsz-jelenséget 1916-ban írták le az Egyesült Királyságban, és "generációs jelenségnek" tartották, majd az 1920-as években a norvég Kristi an F. Andvord (1855-1934) a skandináv adatok alapján megfigyelte, hogy a betegség mortalitása függ az érintett betegek korosztályától [9]. Az Egyesült
}

tottuk a CC, TC és TT fenotípusok gyakoriságát a teljes csoportra, férfiakra és nőkre. A kohorszok közti szignifikanciát ANOVA-teszttel elemeztük. A statisztikai feldolgozást a Sigmastat for Windows, 3.5 verzió, 2006 (Systat Software Inc., San Jose, CA, USA) programmal végeztük.

\section{Eredmények}

A betegek demográfiai adatait az 1. táblázatban ismertetjük. A korcsoportok szerinti megoszlás a 2. táblázatban látható. A születésikohorsz-vizsgálatban a betegszám eloszlása az idősebb betegeknél alacsony, ami statisztikai torzításhoz vezetett, de az 1970 és 1990 közötti időszakban - amikor jelentős a CC-fenotípus gyakoriságának emelkedése - az eloszlás szabályos volt.

1. táblázat | Demográfiai adatok

\begin{tabular}{lccc}
\hline Csoport & Összes & Férfi & Nő \\
\hline Esetszám & 1266 & $398(31,4 \%)$ & $868(68,6 \%)$ \\
Életkor (átlag \pm szórás) & $38,0 \pm 0,4$ & $37,9 \pm 0,6$ & $38,0 \pm 0,5$
\end{tabular}

2. táblázat |A beteganyag korcsoportok szerinti megoszlása

\begin{tabular}{lccc}
\hline Születési kohorsz & Összes eset & Férfi & Nó \\
\hline 1940 előtt & 11 & 4 & 7 \\
$1941-1944$ & 20 & 5 & 15 \\
$1945-1949$ & 26 & 5 & 21 \\
$1950-1954$ & 50 & 14 & 36 \\
$1955-1959$ & 43 & 11 & 32 \\
$1960-1964$ & 53 & 12 & 41 \\
$1965-1969$ & 87 & 29 & 58 \\
$1970-1974$ & 91 & 37 & 54 \\
$1975-1979$ & 168 & 56 & 112 \\
$1980-1984$ & 223 & 87 & 136 \\
$1985-1989$ & 261 & 78 & 183 \\
$1990-1994$ & 180 & 48 & 132 \\
1995 után & 53 & 12 & 41 \\
\hline Összes & 1266 & 398 & 868 \\
\hline
\end{tabular}

Államokban Wade Hampton Frost (1880-1938) vezette be a születésikohorsz elemzést a tuberkulózis epidemiológiájának tanulmányozásába [10]. A gasztroenterológiában a születésikohorsz-elemzést Mervyn Susser (1921-2014), Londonban dolgozó dél-afrikai kutató vezette be, aki az angliai regiszterek alapján a peptikus fekély mortalitását a betegek születési évének és életkorának függvényében ábrázolva kimutatta, hogy az egymást követő korcsoportokban a betegség mortalitása csökken. Eredményei alapján a fekélyt civilizációs betegségnek tartotta, és a korai urbanizációval járó életmódváltozás és stressz következményének vélte [11]. A születésikohorsz-jelenséget utóbb leírták daganatos betegségekben és gyulladásos bélbetegségben is. Mivel a jelenségben a számítások alapjául a születés, és nem a halál éve szerepel, feltételezik, hogy az eredményeket a perinatalis időszakban és fiatalkorban ható kockázati tényezők határozzák meg: ezek szerepét azonban egyik betegségben sem sikerült egyértelmúen igazolni/kizárni [12]. Születésikohorsz-vizsgálat Magyarországon eddig csak a gyermeknövekedés területén történt (Országos Longitudinális Gyermeknövekedés-vizsgálat, 1979-1982) [13]. 


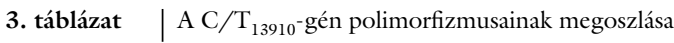

\begin{tabular}{lccl}
\hline $\mathrm{C} / \mathrm{T}_{13910}$-fenotípus & Összes & Férfi & Nő \\
\hline $\mathrm{CC}$ & $570(45,0 \%)$ & $205(16,2 \%)$ & $365(28,8 \%)$ \\
$\mathrm{TC}$ & $542(42,8 \%)$ & $153(12,1 \%)$ & $389(30,7 \%)$ \\
$\mathrm{TT}$ & $154(12,2 \%)$ & $40(3,2 \%)$ & $114(9 \%)$ \\
\hline Összes & $1266(100 \%)$ & $398(31,4 \%)$ & $868(68,6 \%)$ \\
\hline
\end{tabular}

A $\mathrm{C} / \mathrm{T}_{13910^{-}}$gén polimorfizmusainak eloszlását a 3 . táblázatban mutatjuk be. A CC-fenotípus gyakorisága az 1940 és 1990 közötti 5 éves születési kohorszokban az 1 . ábrán látható.

A tejcukor-érzékenységre hajlamosító CC-fenotípus gyakorisága a tanulmányozott korszakban nőkben szignifikánsan, 9,13\%-ról 37,7\%-ra $(\mathrm{p}=0,017)$ emelkedett, míg a a férfiaknál csupán időszakos ingadozások észlelhetők, a CC-fenotípus gyakoriságának szignifikáns emelkedése nélkül: az 1939 előtti években észlelt 18,2\%-os arány versus statisztikai torzításból ered (kis esetszám), de az 1940-es évektől 1964-ig 10,0-7,5\% között változik, majd az 1990-es évekig nem szignifikánsan 14,918,8\%-ra növekszik. Az összesített (férfiak + nők) eredmények szerint a CC-fenotípus gyakorisága az 1940 előtti $27,2 \%$-ról 48,2\%-ra emelkedett ( $\mathrm{p}=0,088$ ), ami elsősorban a nőknek tulajdonítható. Ennek megfelelően nőkben a TC-fenotípus gyakorisága a születési kohorszokban arányosan csökkent, a legritkább TT-fenotípus nem változott.

\section{Megbeszélés}

A felnőttkori hypolactasia világszerte elterjedt, gyakorisága jelentős különbségeket mutat kontinensek és népességek között. Előfordulását genetikai, táplálkozási és éghajlati tényezők befolyásolják [14]. Az eredmények változóak a hypolactasia kimutatására használt módszerek (kérdőíves felmérés, hidrogénkilégzési teszt, geneti- kai teszt), illetve a tanulmányozott esetek (egészséges egyének, betegek) szerint. A felnőtt típusú hypolactasia gyakoriságát Magyarországon elsőként Szakály Sándor (1937-2008) élelmiszer-kémikus és -mérnök értékelte ki: tejcukoroldat itatása után kérdőíves felmérést végzett, és az egyének 7,9\%-ában észlelt tüneteket [15]. Czeizel Endre (1936-2015) és mtsai laktózterhelés utáni vércukorvizsgálattal 37\%-ban észleltek tejcukor-érzékenységet [16], míg Herszényi László hidrogénkilégzési vizsgálattal 51\%-os gyakoriságot talált [17]; 2009-ben a magyar lakosságban genetikai teszttel $37 \%$-os prevalenciát észleltek [18].

2016-os retrospektív tanulmányunkban a fenotípusok megoszlása az alábbi volt. CC: $48,1 \%$, TC: $40,5 \%$, TT: 11,5\% [7]; a retrospektív és a jelenlegi prospektív eredmények azonosak. A CC-fenotípus gyakorisága tanulmányunkban magasabb, mint a környező országokban: Oroszországban 34\% [19], Lengyelországban 26\% [20] és 38\% [21], Ausztriában 19,4\%, illetve 24,1\% [22, 23]; ennek lehetséges oka, hogy esetünkben panaszokkal rendelkező betegeket, és nem általános lakosságot vizsgáltunk.

A felnőttkori hypolactasia változatos földrajzi gyakoriságának magyarázatára több elméletet dolgoztak ki. A nutritív gátlás elméletét 1969-ben közölték, e szerint a laktóz - vagy valamilyen, eddig nem ismert tápanyag, például más szénhidrátok, de gyógyszer is - rendszeres fogyasztása a laktáz gátlásához vezet [24].

1970-ben fogalmazták meg a genetikai-kulturális közös fejlődés elméletét, miszerint a laktózfogyasztás táplálkozási előnyt jelentett a letelepedett, pasztorális népcsoportoknál, amelyek állattenyésztéssel foglalkoztak, szemben a nomád, gyújtögető-vadász életmódot folytató népekkel [25]. A laktózintolerancia eltérő gyakoriságát azzal magyarázták, hogy e folyamat földrajzi régiónként különböző időszakokban következett be. A kalciumasszimilációs elmélet szerint a laktázgén perzisztenciája olyan magaslati területeken alakult ki, ahol a

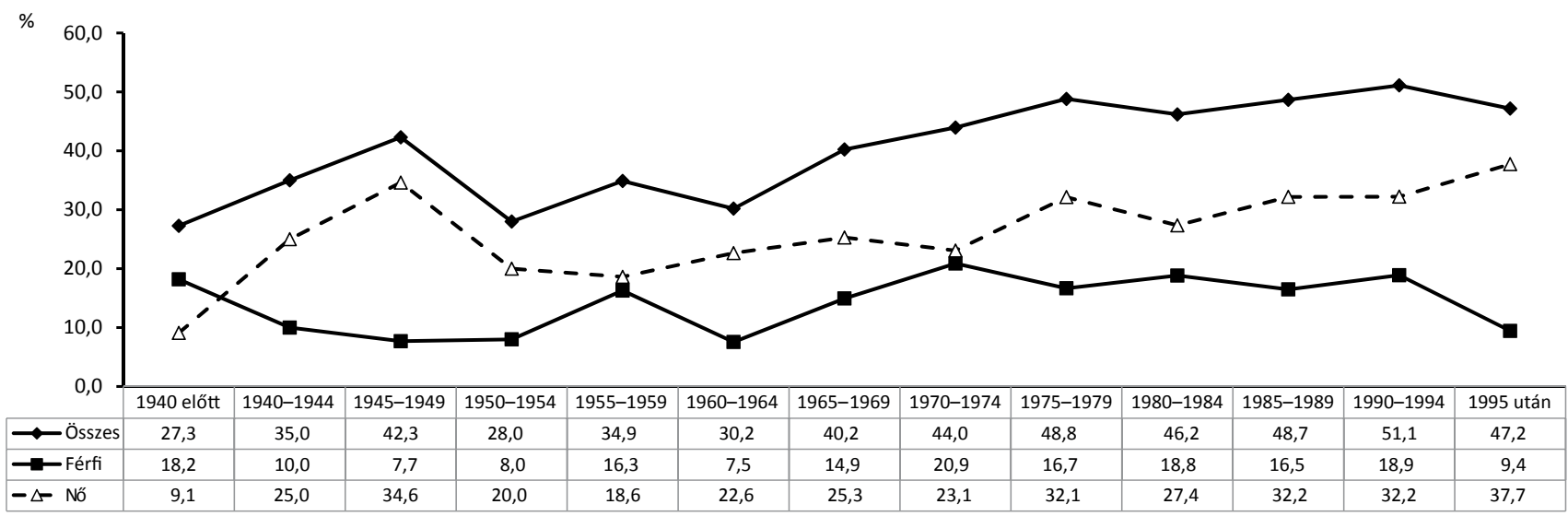

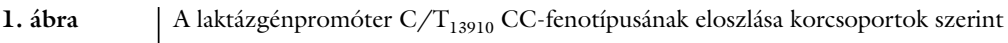

$\mathrm{CC}=$ citozin-citozin 
laktóz a kevés napsütés miatt a D-vitamint helyettesíti, és így a fokozott kalciumfelszívódás révén megelőzi az angolkórt (1973) [26]. 1997-ben azt feltételezték, hogy a laktázperzisztencia elsősorban olyan aszályos területeken alakult ki, ahol a tej fogyasztása a kiszáradást előzte meg [27].

A felnőttkori hypolactasia gyakoriságának jelenkori földrajzi változásait egyik elmélet sem magyarázza, és arra sem ad választ, hány generáción át kell hatnia egy tényezőnek ahhoz, hogy a mutáció bekövetkezzen, holott genetikai és környezeti tényezők az utóbbi évtizedekben is hatottak $[2,25-28]$.

Beteganyagunkban a tejcukor-érzékenységre hajlamosító CC-fenotípus aránya az elmúlt évtizedekben elsősorban nókben növekedett, így felmerül a hormonális hatás(ok) lehetősége. Az anamnézis során nem tértünk ki olyan részletekre, mint a laktózintolerancia előfordulása a szülőknél, testvéreknél, az anyai fogamzásgátlás, esetleges hormonkezelések, így ilyen irányú következtetéseket nem tudunk levonni.

A hormonok laktázgénre gyakorolt hatásáról kevés adat áll rendelkezésre. Éheztetett patkányokban a laktázgén expresszióját a szukróz növeli, de ez csak normális pajzsmirigymúködés esetében nyilvánul meg [29]. Szoptatott patkánykölykökben a tiroxin csökkentette, a kortizon növelte, az inzulin viszont nem befolyásolta a vékonybél-kefeszegélyben mért laktázaktivitást [30]. Tenyésztett vékonybél-epithelsejtekben a szteroidok és a tiroxin szinergikusan növelték a laktázgén expresszióját [31].

A nemi hormonok hatása a laktázgénre emberben nem ismert. Svéd tanulmányban azt észlelték, hogy az oxitocin génpolimorfizmusa szignifikánsan gyakrabban társul laktázgén-nonperzisztenciával (CC-fenotípus) [32]. Teljesepigenom-vizsgálattal kimutatták, hogy a laktázgén promóterének DNS-metilációja a $\mathrm{C} / \mathrm{T}_{13910^{-}}$ fenotípussal asszociált, ami laktázperzisztenciával jár. A DNS-metiláció meghatározása diagnosztikai jelentőséggel bírhat a laktázfenotípusok elkülönítésében [33], de nem magyarázza eredményeinket.

A fenti kísérleti és humángenetikai eredmények nem magyarázzák meg a CC-fenotípus gyakoriságának növekedését az utóbbi évtizedekben, így további kutatások szükségesek.

A hazai lakosság tej- és tejterméktermelése és -fogyasztása az utóbbi 3 évtizedben folyamatosan növekedett: az adatok fellelhetők az OGYÉI és a KSH honlapján [34, 35] és tanulmányokban [36]. Nincs olyan közlemény, amely a fogyasztást az általunk lefedett teljes időszakra elemezné, de az adatok szerint az egy före jutó tejtermékfogyasztás az 1990-es 135,2kg-ról 2016-ban 169,0 kg-ra emelkedett.

A tejfogyasztás hatására a laktáz enzim aktivitása patkányokban növekszik, és a tej megvonására nem csökken [37]. Izraeli kísérletben 10 önkéntesnek 9-14 hónapig adtak növekvő adagban naponta tejet, de sem a laktózterhelési teszt, sem a vékonybél laktázaktivitása nem vál- tozott, azaz az enzim nem alkalmazkodott a táplálkozási körülményekhez [38]. A táplálkozás hosszú távú hatása a laktáz aktivitására nem ismert. Betegeink táplálkozási naplót, étkezési szokásaikra vonatkozó kérdőívet nem vezettek, így ilyen irányú adataink nincsenek.

A laktázgén promóterének CC-genotípusa a tejcukorérzékenységre való hajlamot jelzi. Gyakoriságának növekedése nőkben további kutatásokat igényel, hiszen a laktózintolerancia épp emiatt népegészségügyi jelentőségú betegség. Bár nem csökkenti az átlagos élettartamot, rontja e betegek életminőségét, ezáltal munkájuk hatékonyságát, növeli a betegségben eltöltött napok számát $[4,5]$. Hosszú távú következményei között említendő - fóképp nőkben - az osteoporosis, amely a csökkent kalciumbevitel miatt alakul ki: 2018-as metaanalízis igazolja, hogy laktózintolerancia menopauza után csökkenti a csontsűrüséget, és növeli az osteoporosis kockázatát, ezért az idősebb nőbetegeket ilyen irányban szürni kell [39, 40]. Tisztázatlan a tejcukor-érzékenység és a rák kapcsolata. Hazai tanulmányban a CC-fenotípus nem növelte a vastagbélrák kockázatát, de a betegekben növelte a metasztázisok gyakoriságát, és csökkentette a túlélés időtartamát. Finn [41] adatok szerint CC-fenotípusú egyénekben a colorectalis carcinoma kockázata magasabb, de ezt olasz, angol, spanyol és török lakosságban nem sikerült igazolni $[8,42]$ : mindez evidenciának kevés, így a vastagbélrák szürése tejcukorérzékenyeknél nem indokolt.

Dolgozatunk előnye, hogy nagyszámú beteganyagon robusztus módszerrel értékelte ki a laktázgén promóterében a polimorfizmusok gyakoriságát: az áttekintett irodalomban esetszámunk a legnagyobb. A retrospektíven és prospektíven vizsgált betegekben a polimorfizmusok eloszlása azonos volt, így az adatok összevonhatók és a fenotípus - akárcsak a születési év vagy a mortalitás - stabil végpontnak tekinthető. A születésikohorsz-jelenség leírása tejcukor-érzékenységben prioritás, erre vonatkozó irodalmi adatot nem találtunk. A munka hátránya, hogy nem általános lakosságot, hanem egy betegcsoportot értékelt ki, így abban a laktázgén promóter polimorfizmusainak aránya valószínúleg eltérő.

Anyagi támogatás: A közlemény megírása és a kutatómunka anyagi támogatásban nem részesült.

A cikk végleges változatát a szerző elolvasta és jóváhagyta.

Érdekeltségek: A szerzőnek nincsenek érdekeltségei.

\section{Köszönetnyilvánítás}

A szerző köszönettel tartozik a genetikai tesztek elvégzéséért és értelmezéséért Dr. Fodor Flóra főorvosnőnek (Synlab, GenoID Molekuláris Diagnosztikai Laboratórium), a genetikai mintavételek elvégzéséért Nagy Judit, Szilágyi Éva, Magyari Erika, Gallai Henriette (Ferencvárosi Egészségügyi Szolgáltató Kft.) endoszkópos asszisztensnőknek, 
valamint Józan Jolánnak a statisztikai feldolgozásért és szövegszerkesztésért. Az irodalomkutatásért Oláh Ilonának (Semmelweis Egyetem, Élettan), az angol összefoglaló nyelvi lektorálásáért Douglas Arnott úrnak (EDMF Translations Kft., Budapest) jár köszönet.

\section{Irodalom}

[1] Gasztonyi B, Bajor J, Tihanyi M, et al. Current clinical approach of lactose intolerance. [A laktózintolerancia gyakorlati megközelítése.] Gasztroenterol Hepatol Szle. 2018; 4: 31-35. [Hungarian]

[2] Ségurel L, Bon C. On the evolution of lactase persistence in humans. Annu Rev Genomics Hum Genet. 2017; 18: 297-319.

[3] Buzás GyM. Lactose intolerance: past and present. Part I. [A laktózintoleranciáról: Múlt és jelen - I. rész.] Orv Hetil. 2015; 156 : 1532-1539. [Hungarian]

[4] Buzás GyM. Lactose intolerance: past and present. Part II. [A laktózintoleranciáról: Múlt és jelen - II. rész.] Orv Hetil. 2015; 156: 1741-1749. [Hungarian]

[5] Buzás GyM. Current view of lactose intolerance. [A laktózintolerancia aktuális szemlélete.] Magy Belorv Arch. 2017; 70: 191197. [Hungarian]

[6] Rónai Z, Lippai Z, Elek Z, et al. Investigation of the genetic background of complex diseases. [Komplex jellegek genetikai hátterének vizsgálata.] Orv Hetil. 2018; 159: 1254-1261. [Hungarian]

[7] Buzás GyM, Fodor F, Csókay B. Accuracy of lactase gene C/T13910 polymorphism and hydrogen breath test in a gastroenterology outpatient clinic: a retrospective study. [Laktózintolerancia: a laktázgén C/T-13910 polimorfizmusának és a hidrogénkilégzési teszt pontosságának retrospektív kiértékelése gasztroenterológiai szakrendelésen.] Orv Hetil. 2016; 157: 1007-1012. [Hungarian]

[8] Bácsi K, Hitre E, Kósa JP, et al. Effects of the lactase 13910 C/T and calcium-sensor receptor A986S G/T gene polymorphisms on the incidence and recurrence of colorectal cancer in Hungarian population. BMC Cancer 2008; 8: 317.

[9] Andvord KF. What can we learn by following the development of tuberculosis from one generation to another? Int J Tuberc Lung Dis. $2002 ; 6: 562-568$.

[10] Frost WH. The age selection of mortality from tuberculosis in succesive decades. Am J Hyg. 1939; 30: 91-96.

[11] Susser M, Stein Z. Civilization and peptic ulcer. Lancet 1962; 1(7221): 115-119.

[12] Sonnenberg A, Cucino C, Bauerfeind P. Commentary: the unresolved mystery of birth-cohort phenomena in gastroenterology. Int J Epidemiol. 2002; 31: 23-26.

[13] Blaskó Zs. Birth-cohort analyses in Hungary and abroad: experience and lessons. [Születési kohorsz-vizsgálatok itthon és külföldön - tapasztalatok és tanulságok.] Esély 2009; 6: 45-75. [Hungarian]

[14] Liebert A, López S, Jones BL, et al. World-wide distribution of lactase persistence alleles and the complex effects of recombination and selection. Hum Genet. 2017; 136: 1445-1453.

[15] Szakály S, Facskó M, Schrom J, et al. Results of lactose intolerance assessment in Hungary. In: Mózsik Gy, Jávor T, Szakály S. (eds.) Current state and tasks of dietetics in Hungary, 1981. [A hazai laktózintolerancia felmérésének eredményei. In: Mózsik Gy, Jávor T, Szakály S. (szerk.) A táplálkozástudomány helyzete és feladatai Magyarországon, 1981.] Akadémiai Kiadó, Budapest, 1983; pp. 101-113. [Hungarian]

[16] Flatz G, Czeizel E, Flatz SD. Prevalence of adult lactose malabsorbtion in Hungary. [A felnőttkori elsődleges laktózmalabszorbció prevalenciája Magyarországon.] Orv Hetil. 1984; 125: 147-151. [Hungarian]

[17] Herszényi L, Miskolczi K, Tolnay E, et al. Experience with hydrogen $\left(\mathrm{H}_{2}\right)$ breath test. [Hidrogén $\mathrm{H}_{2}$-kilégzési vizsgálattal szerzett tapasztalataink.] Orv Hetil. 1992; 133: 2483-2487. [Hungarian]

[18] Nagy D, Bogácsi-Szabó E, Várkonyi A, et al. Prevalence of adulttype hypolactasia as diagnosed with genetic and lactose hydrogen breath tests in Hungarians. Eur J Clin Nutr. 2009; 63: 909-912.

[19] Borinskaia SA, Rebrikov DV, Nefedova VC, et al. Molecular diagnosis and frequencies of primary hypolactasia in populations of Russia and neighboring countries. Mol Biol. 2006; 40: 10311036.

[20] Krawczyk M, Wolska M, Schwartz S, et al. Concordance of genetic and breath tests for lactose intolerance in a tertiary referral centre. J Gastrointestin Liver Dis. 2008; 17: 135-139.

[21] Madry E, Lisowka A, Kwiecień J, et al. Adult-type hypolactasia and lactose malabsorption in Poland. Acta Biochim Pol. 2010; 57: 585-588.

[22] Högenauer C, Hammer HF, Mellitzer K, et al. Evaluation of a new DNA test compared with the lactose hydrogen breath test for the diagnosis of lactase non-persistence. Eur J Gastroenterol. 2005; 17: 371-376.

[23] Enko D, Rezanka E, Stolba R, et al. Lactose malabsorption testing in daily clinical practice: a critical retrospective analysis and comparison of the hydrogen/methane breath test and genetic test (C/T-13910 polymorphism) results. Gastroenterol Res Pract. 2014; 2014: 464382.

[24] Simoons FJ. Primary adult lactose intolerance and the milking habit: a problem in biologic and cultural interrelations. II. A culture-historical hypothesis. Am J Dig Dis. 1970; 15: 695-710.

[25] Alpers DH. Inhibition of intestinal lactase. A possible role in lactose intolerance. Clin Res. 1969; 17: 296.

[26] Flatz G, Rotthauwe HW. Lactose nutrition and natural selection. Lancet 1973; 2(7820): 76-77.

[27] Holden C, Mace R. Phylogenetic analysis of the evolution of lactose digestion in adults. Hum Biol. 1997; 69: 605-628.

[28] Gerbault P, Moret C, Currat M, et al. Impact of selection and demography on the diffusion of lactase persistence. PLoS ONE 2009; 4: e6369.

[29] Kuranuki S, Mochizuki K, Goda T. Dietary sucrose enhances intestinal lactase gene expression in euthyroid rats. J Nutr Sci Vitaminol. 2006; 52: 347-351.

[30] Chaudhry KK, Mahmood S, Mahmood A. Hormone induced expression of brush border lactase in suckling rat intestine. Mol Cell Biochem. 2008; 312: 11-16.

[31] Suzuki T, Mochizuki K, Goda T. Thyroid and glucocorticoid hormones induce expression of lactase-phlorizin hydrolase gene in CDX-2/HNF- $1 \alpha$ co-transfected IEC- 6 cells. J Nutr Sci Vitaminol. 2014; 60: 321-327.

[32] Truedsson M, Carlson J, Simrén M, et al. Polymorphism in the oxytocin promoter region in patients with lactase non-persistence is not related to symptoms. BMC Gastroenterol. 2009; 9: 90.

[33] Leseva MN, Grand RL, Klett H, et al. Differences in DNA methylation and functional expression in lactase persistent and nonpersistent individuals. Sci Rep. 2018; 8: 5649.

[34] http: www.ogyei.gov.hu/dynamic/OTAP2014ø20tejtermek\%20 fogy. PDF [Hungarian]

[35] http://www.ksh.hu/docs/hun/xstadat/xstadat_eves/i_ qpt011b.html [Hungarian]

[36] Sarkadi Nagy E, Bakács M, Illés É, et al. Hungarian Diet and Nutritional Status Survey - OTÁP2014. II. Energy and macronutrient intake of the Hungarian population. [Országos Táplálkozás és Tápláltsági Állapot Vizsgálat - OTÁP2014. II. A magyar lakosság energia- és makrotápanyag-bevitele.] Orv Hetil. 2017; 158: 587-597.

[37] Bolin TD, Pirola RC, Davis AE. Adaptation of intestinal lactase in the rat. Gastroenterology 1969; 57: 406-409.

[38] Gilat T, Russo S, Gelman-Malachi E, et al. Lactase in man: a nonadaptable enzyme. Gastroenterology 1972; 62: 1125-1127. 
[39] Treister-Goltzman Y, Friger M, Peleg R. Does primary lactase deficiency reduce bone mineral density in postmenopausal women? A systematic review and meta-analysis. Osteoporosis Int. 2018; 29: 2399-2407.

[40] Marangoni F, Pellegrino L, Verduci E, et al. Cow's milk consumption and health: a health professional's guide. J Am Coll Nutr. 2018 Sep 24. 10.1080/07315724. 2018.1491016. [Epub ahead of print]

[41] Rasinperä H, Forsblom C, Ennatah NS, et al. The C/C -13910 genotype of adult-type hypolactasia is associated with an in- creased risk of colorectal cancer in the Finnish population. Gut 2005; 54: 643-647.

[42] Gençdal G, Salman E, Özütemiz Ö, et al. Association of LCT$13910 \mathrm{C} / \mathrm{T}$ polymorphism and colorectal cancer. Ann Coloproctol. 2017; 33: 169-172.

(Buzás György Miklós dr., Budapest, Mester u. 45., 1095 e-mail:drbgym@gmail.com)

"Exceptio firmat regulam."

(Kivétel erősíti a szabályt.)

\section{ELADÓ PRAXIS}

Soproni, Harka csatolt községgel bővített 2500 fős felnőtt háziorvosi praxisomat nyugdijjazás miatt eladnám, foglalkozás-egészségügyi praxisom későbbi átadásának lehetőségével. Munkájára igényes kolléga jelentkezését várom!

e-mail: videograf@t-online.hu 